\title{
Does rapamycin slow down time?
}

\section{Mikhail V. Blagosklonny}

According to Einstein's theory, time is relative and can be made to move slower by increasing the speed of the observer. In the famous twin paradox, this slowing of time enables one identical twin to live longer than the other. Animals treated with rapamycin, an inhibitor of mTOR, also live longer [1-5]. Of course, that does not mean that rapamycin slows time in the Einsteinian sense. Instead, it figuratively slows biological time by slowing seemingly opposite processes. On the one hand, rapamycin (and other mTOR inhibitors) retards cell proliferation, while on the other hand, it retards loss of proliferative potential $[6,7]$. In other words, rapamycin decelerates proliferation while preserving the potential to proliferate. In that way, rapamycin suppresses both cell growth and geroconversion (conversion to senescence). It has been calculated that rapamycin slows geroconversion by approximately 3 -fold [6]. By doing so, rapamycin slows development and aging, reproduction and menopause, and hyperfunction and functional decline [8]. This is because in each case one process is a continuation of the other (Figure 1,2). For example, aging is a continuation of developmental growth (Figure 1), and functional decline (loss of function, Figure 2) results from earlier hyperfunction [8].

The slowing of biological time entails "suppression plus preservation." For example, by suppressing betacell function, rapamycin preserves beta-cell function in the long run [9-11]; or by suppressing reproduction, it preserves the oocytes, thereby delaying menopause [1214]. In theory, a woman who wants to have children later in life could postpone reproduction using rapamycin. This

A

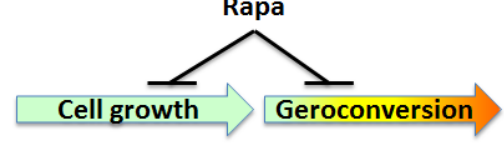

B

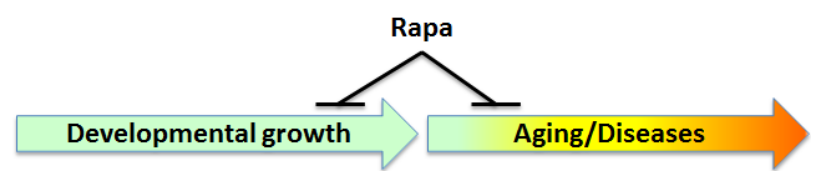

Figure 1: Rapamycin slows aging. A. Cell culture. In proliferating cells, rapamycin (RAPA) slows growth. When the cell is arrested, then rapamycin slows down geroconversion to senescence. Geroconversion is a continuation of growth in nondividing (arrested) cells. B. The organism. When development is completed, then mTOR drives aging and age-related diseases. Thus, aging and its diseases are quasi-programmed (a continuation of developmental growth). RAPA slows aging and delays diseases. can be seen as "freezing the ovaries" until later in life. Rapamycin suppresses cellular hyperfunction and thus delays all diseases of aging, from cancer to Alzheimer's [8]. Pathological processes such as age-related diseases are continuations (or exacerbations) of physiological processes. Geroconversion is a continuation of growth (Figure 1), hyperfunction is a continuation of tissuespecific cellular function (Figure 2), age-related hypertension and presbyopia are continuations of developmental trends (see Figure 3 in ref. 15). Therefore, aging is both hyperfunctional and quasi-programmed [8, 16, 17]. (A quasi-program is a purposeless continuation of a developmental program.) Hyperfunction eventually leads to organ damage and functional decline [8, 15]. By suppressing hyperfunction, rapamycin delays organ damage (e.g., infarction) and loss of organ function [8, 15]. In addition to their therapeutic effects, the side effects of rapalogs are also consequences of slowing down time. For example, by slowing cell proliferation, high doses of rapamycin induce reversible anemia, mucositis and skin rash.

So why does rapamycin do all that? Rapamycin is produced by the bacterium Streptomyces hygroscopicus, which lives in the soil of Easter island [18]. This wonderful microbe had no intention of slowing time on its mysterious island; instead, it sought to slow down the growth of fungi, its natural enemy. But since rapamycin slows growth, it should also slow aging if aging is a continuation of growth. In fact, it does just that; rapamycin prolongs the lifespan of yeast [19].

Rapalogs (rapamycin, everolimus, temsirolimus and deforolimus) are allosteric inhibitors of mTOR complex 1, a central regulator of RNA translation and cellular growth and metabolism [20-23]. mTOR enhances translation of TOP and TOP-like mRNAs $[22,23]$. Rapamycin and, especially, the pan-mTOR inhibitor Torin1 slow this translation $[22,23]$. This raises the question, is slowing translation equivalent to slowing time and, if so, can biological time be measured based on the speed of translation?

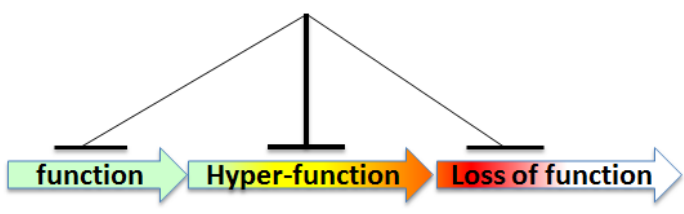

Figure 2: Rapamycin decreases hyper-functions, a key feature of aging, thus preventing functional decline 
The answer to that question is, not entirely. Although mTOR inhibitors may in principle "slow time" by slowing rapamycin-sensitive translation from mRNA to protein, this does not completely explain the gerosuppressive effects of rapamycin or pan-mTOR inhibitors. In fact, inhibitors of S6 kinase slightly exhibit gerosuppressive activities [24], even though S6 kinase is not crucial for RNA translation [23]. So, mTOR inhibitors may affect the speed of aging by suppressing geroconversion (Figure 1) and cellular function and hyperfunction (Figure 2) independently of TOP mRNA translation. In addition, rapamycin also slows age-related methylation, or the epigenetic clock [25-29].

Another intriguing possibility is that rapamycin slows time by slowing the circadian clock. mTOR inhibition slows the circadian clock and dampens clock oscillations, whereas mTOR activation accelerates the clock and enhances clock oscillations at the level of cells, tissues and mice [30]. Conversely, circadian clock mediators affect the mTOR pathway and aging [31]. Because mTOR activity is itself part of the circadian clock, its sensitivity to rapamycin can vary widely depending on the time of the day and the phase of the clock [32]. This should be taken into account when comparing the numerous studies in mouse models. It should also be taken into account when designing rapamycin-based therapies for aging.

Rapamycin has been combined with several lifeextending drugs in the "Koschei" formula [5]. This rapamycin-based drug combination has been successfully used as an anti-aging therapy at the Alan Green clinic https://rapamycintherapy.com

https://roguehealthandfitness.com/rapamycinanti-aging-medicine-an-interview-with-alan-s-green-m$\mathrm{d} /$ ?print=pdf

The older we become, the faster time flies. It is initially measured in days, then in weeks, the four seasons, and finally "Winter-Summer" cycles. Of course, this is an illusion, but an annoying one. Would treatment with rapamycin enable us to notice Spring again?

Mikhail V. Blagosklonny: Roswell Park Cancer Institute, Buffalo, NY, USA

Correspondence to: Mikhail V. Blagosklonny,

email Mikhail.blagosklonny@roswellpark.org

email blagosklonny@rapalogs.com

Keywords: rapalogs; mTOR; aging; growth; lifespan

Received: July 03, 2018

Published: July 13, 2018

\section{REFERENCES}

1. Johnson SC, Kaeberlein M. Rapamycin in aging and disease: maximizing efficacy while minimizing side effects.
Oncotarget. 2016; 7:44876-44878.

https://doi.org/10.18632/oncotarget.10381.

2. Christy B, Demaria M, Campisi J, Huang J, Jones D, Dodds SG, Williams C, Hubbard G, Livi CB, Gao X, Weintraub S, Curiel T, Sharp ZD, Hasty P. p53 and rapamycin are additive. Oncotarget. 2015; 6:15802-13.

https://doi.org/10.18632/oncotarget.4602

3. Kaeberlein M. The Biology of Aging: Citizen Scientists and Their Pets as a Bridge Between Research on Model Organisms and Human Subjects. Vet Pathol. 2016; 53:2918. https://doi.org/10.1177/0300985815591082.

4. Kaeberlein M, Kennedy BK. Ageing: A midlife longevity drug? Nature. 2009; 460:331-2.

https://doi.org/10.1038/460331a.

5. Blagosklonny MV. From rapalogs to anti-aging formula. Oncotarget. 2017; 8:35492-35507.

https://doi.org/10.18632/oncotarget.18033.

6. Demidenko ZN, Zubova SG, Bukreeva EI, Pospelov VA, Pospelova TV, Blagosklonny MV. Rapamycin decelerates cellular senescence. Cell Cycle. 2009; 8:1888-95.

7. Leontieva OV, Blagosklonny MV. Gerosuppression by panmTOR inhibitors. Aging (Albany NY). 2016; 8:3535-3551. https://doi.org/10.18632/aging.101155.

8. Blagosklonny MV. Aging and immortality: quasiprogrammed senescence and its pharmacologic inhibition. Cell Cycle. 2006; 5:2087-102.

9. Blagosklonny MV. TOR-centric view on insulin resistance and diabetic complications: perspective for endocrinologists and gerontologists. Cell Death Dis. 2013;4:e964.

https://doi.org/10.1038/cddis.2013.506.

10. Reifsnyder PC, Flurkey K, Te A, Harrison DE. Rapamycin treatment benefits glucose metabolism in mouse models of type 2 diabetes. Aging (Albany NY). 2016; 8:3120-3130. https://doi.org/10.18632/aging.101117.

11. Ardestani A, Lupse B, Kido Y, Leibowitz G, Maedler K. mTORC1 Signaling: A Double-Edged Sword in Diabetic $\beta$ Cells. Cell Metab. 2018; 27:314-331. https://doi.org/10.1016/j.cmet.2017.11.004.

12. Blagosklonny MV. Why men age faster but reproduce longer than women: mTOR and evolutionary perspectives. Aging (Albany NY). 2010; 2:265-73. https://doi.org/10.18632/aging.100149

13. Dou X, Sun Y, Li J, Zhang J, Hao D, Liu W, Wu R, Kong F, Peng X, Li J. Short-term rapamycin treatment increases ovarian lifespan in young and middle-aged female mice. Aging Cell. 2017; 16:825-836.

https://doi.org/10.1111/acel.12617.

14. Luo LL, Xu JJ, Fu YC. Rapamycin prolongs female reproductive lifespan. Cell Cycle. 2013; 12:3353-4.

https://doi.org/10.4161/cc.26578. 
15. Blagosklonny MV. Answering the ultimate question "what is the proximal cause of aging?". Aging (Albany NY). 2012; 4:861-77. https://doi.org/10.18632/aging.100525

16. Gems D, de la Guardia Y. Alternative Perspectives on Aging in Caenorhabditis elegans: Reactive Oxygen Species or Hyperfunction? Antioxid Redox Signal. 2013; 19:321-9. https://doi.org/10.1089/ars.2012.4840.

17. Wang H, Zhao Y, Ezcurra M, Benedetto A, Gilliat AF, Hellberg J, Ren Z, Galimov ER, Athigapanich T, Girstmair J, Telford MJ, Dolphin CT, Zhang Z, Gems D. A parthenogenetic quasi-program causes teratoma-like tumors during aging in wild-type C. elegans. NPJ Aging Mech Dis. 2018; 13;4:6.

18. Stipp D. A new path to longevity. Sci Am. 2012; 306:32-9.

19. Longo VD, Shadel GS, Kaeberlein M, Kennedy B. Replicative and chronological aging in Saccharomyces cerevisiae. Cell Metab. 2012; 16:18-31. https://doi.org/10.1016/j.cmet.2012.06.002.

20. Hall MN. An Amazing Turn of Events. Cell. 2017; 171:1822. https://doi.org/10.1016/j.cell.2017.08.021.

21. Hall MN. TOR and paradigm change: cell growth is controlled. Mol Biol Cell. 2016; 27:2804-6

22. Thoreen CC, Chantranupong L, Keys HR, Wang T, Gray NS, Sabatini DM. A unifying model for mTORC1-mediated regulation of mRNA translation. Nature. 2012; 485:109-13.

23. Thoreen CC, Kang SA, Chang JW, Liu Q, Zhang J, Gao Y, Reichling LJ, Sim T, Sabatini DM, Gray NS. An ATPcompetitive mammalian target of rapamycin inhibitor reveals rapamycin-resistant functions of mTORC1. J Biol Chem. 2009; 284:8023-32.

24. Leontieva OV, Demidenko ZN, Blagosklonny MV. S6K in geroconversion. Cell Cycle. 2013; 12:3249-52.

25. Epigenetic aging signatures in mice livers are slowed by dwarfism, calorie restriction and rapamycin treatment. Wang T, Tsui B, Kreisberg JF, Robertson NA, Gross AM, Yu MK, Carter H, Brown-Borg HM, Adams PD, Ideker T. Genome Biol. 2017; 18:57.

https://doi.org/10.1186/s13059-017-1186-2.

26. Cole JJ, Robertson NA, Rather MI, Thomson JP, McBryan T, Sproul D, Wang T, Brock C, Clark W, Ideker T, Meehan RR, Miller RA, Brown-Borg HM, Adams PD. Diverse interventions that extend mouse lifespan suppress shared age-associated epigenetic changes at critical gene regulatory regions. Genome Biol. 2017; 18:58.

https://doi.org/10.1186/s13059-017-1185-3.

27. Karunadharma PP, Basisty N, Dai DF, Chiao YA, Quarles EK, Hsieh EJ, Crispin D, Bielas JH, Ericson NG, Beyer RP, MacKay VL, MacCoss MJ, Rabinovitch PS. Subacute calorie restriction and rapamycin discordantly alter mouse liver proteome homeostasis and reverse aging effects.
Aging Cell. 2015; 14:547-57.

https://doi.org/10.1111/acel.12317.

28. Pellegrini C, Columbaro M, Capanni C, D'Apice MR, Cavallo C, Murdocca M, Lattanzi G, Squarzoni S. All-trans retinoic acid and rapamycin normalize Hutchinson Gilford progeria fibroblast phenotype. Oncotarget. 2015; 6:2991428.

https://doi.org/10.18632/oncotarget.4939.

29. Gong H, Qian H, Ertl R, Astle CM, Wang GG, Harrison $\mathrm{DE}, \mathrm{Xu} \mathrm{X}$. Histone modifications change with age, dietary restriction and rapamycin treatment in mouse brain. Oncotarget. 2015; 6:15882-90.

https://doi.org/10.18632/oncotarget.4137

30. Ramanathan C, Kathale ND, Liu D, Lee C, Freeman DA, Hogenesch JB, Cao R, Liu AC. mTOR signaling regulates central and peripheral circadian clock function. PLoS Genet. 2018; 14:e1007369.

https://doi.org/10.1371/journal.pgen.1007369.

31. Khapre RV, Kondratova AA, Patel S, Dubrovsky Y, Wrobel M, Antoch MP, Kondratov RV. BMAL1-dependent regulation of the mTOR signaling pathway delays aging. Aging (Albany NY). 2014; 6:48-57. https://doi.org/10.18632/aging.100633

32. Zhang Y, Giacchetti S, Parouchev A, Hadadi E, Li X, Dallmann R, Xandri-Monje H, Portier L, Adam R, Lévi F, Dulong S, Chang Y. Dosing time dependent in vitro pharmacodynamics of Everolimus despite a defective circadian clock. Cell Cycle. 2018; 17:33-42. https://doi.org/10.1080/15384101.2017.1387695.

\section{Further Reading}

https://www.ncbi.nlm.nih.gov/pubmed/?term=blagosklonny+rapamycin+aging

Copyright: Blagosklonny et al. This is an open-access article distributed under the terms of the Creative Commons Attribution License 3.0 (CC BY 3.0), which permits unrestricted use, distribution, and reproduction in any medium, provided the original author and source are credited. 